\title{
The Impact of Jordan's Conventional and Islamic Banking Development Factors on Economic Growth
}

\author{
Nafith Fayez AL-Hersh ${ }^{1}$ \\ ${ }^{1}$ Islamic Banking Specialist - Researcher, Jordan \\ Correspondence: Nafith Fayez AL-Hersh, P. O. Box 213411, AL-Hussien AL-Sharqi 11121, Amman, Jordan. Tel: \\ 962-796-101-778. E-mail: nafez1974@yahoo.com
}

Received: July 1, 2016

doi:10.5539/ijef.v8n9p148
Accepted: August 1, 2016

Online Published: August 25, 2016

URL: http://dx.doi.org/10.5539/ijef.v8n9p148

\begin{abstract}
This study aimed to explore the impact of Jordan's Conventional and Islamic Banking Development Factors on Economic Growth during the period (2000-2015). A sample of four Islamic banks and eight conventional banks was tested. A group of statistical methods such as Multiple Regression, Correlation, Variance Inflation Factor (VIF), T-Test, were applied. The study found that there is significant different between the impact of Conventional and Islamic Banking Factors on RGDP attributed to Total Assets, Liquid Assets, Total Deposits and Total Facilities. In addition, Islamic banks had a much impact on Economic growth as compared to conventional banks. The study recommended the Islamic Banking Sector to introduce a new innovative financial instruments and tools to push the economic growth forward and to increase the investment opportunity and lead to higher contribution to Economic Growth in Jordan.
\end{abstract}

Keywords: Islamic banking development, economic growth, Total Assets of Islamic banks (TAIB), Liquid Assets (LAIB), Total Deposits (TDIB), Total Facilities (TFIB), Net Income (NIIB)

\section{Introduction}

Islamic banking is a global player in the increasingly sophisticated business in current world. The top Islamic financial institutions survey indicated that the market is continuing to move in the right direction, with sharia-compliant institutions improving access to delivery of services, developing microfinance services, and forming stronger strategic partnerships across Asia (The bankers report, 2015). Jordan ranked nine among the top ten countries in Islamic finance with score of global Islamic economy indicator GIEI 35, while Malaysia ranked first (GIEI 116), UAE came second (GIEI 63) and Bahrain third (GIEI 58) (Thomson Reuters Report, 2015). The current population of Jordan is 7,379,600 based on the latest United Nations estimates. Total Gross domestic product reached to 30.204 Billion USD with growth of $2.38 \%$ in 2015 according to last statistics (Reuters, 2016). Muslims account around 92\% of Jordan population. Most of them are Sunni Muslims. This is the highest percentage of Sunni Muslims in the world. There is a Christian minority of about $6 \% \& 2 \%$ others such as Druze. Experts revealed that more than $50 \%$ of people prefer to deal with Islamic banks. Islamic finance received strong support from Jordanian government despite being a small part of the Jordanian banking system. The formative years began by establishing Jordan Islamic bank in 1978 (JIB, Annual Financial Report, 1980). Islamic International Arab bank was followed after two decades in 1997 (IIAB, Annual Financial Report, 1998). In 2010 \& 2011 Jordan Dubai Islamic bank (JDIB, Annual Financial Report, 2010) \& AL-Rajhi bank (RJB, Annual Financial Report, 2012). All of above were established respectively. The government was issued a special law for the establishment of the first Islamic bank. Jordan banking system consisted of sixteen local banks (thirteen conventional \& three Islamic); and nine foreign banks (eight conventional \& one Islamic) (ABJ, Annual Report, 2014).

Islamic banks in Jordan introduced different products based on sharia standards such as Saving accounts, Wakalah, long term accounts \& Commodities. Facilities were also introduced through Qard Hasan, Murabaha, Musawama, Ijara and Jua'lah (AL-Hersh, 2015). Currently, Jordan has four operating Islamic banks, six Islamic finance \& investment companies and two Islamic insurance companies. Islamic banks inside Jordan have around 140 branches in 2015. In term of financial sector total deposits for Islamic banks are expected to be around $18 \%$ from total deposits, while total equities are expected to be around $11 \%$ of total equities for working banks in Jordan. Total assets were $14.9 \%$ in 2014 \& expected to reach (15\%-17\%) of total assets of the banking system in 
2015 .In addition; total liabilities for Islamic banks were $21.8 \%$ in 2014 \& expected to reach the level (22\%-25\%) of total liabilities of the banking system in 2015 (ABJ, Annual Report, 2014).

\section{The Study Motivation}

With regarding to Islamic banks in Jordan, this paper is the first attempt to explore new independent variables as indicators for the Islamic banking development such as Total Assets of Islamic banks (TAIB), Liquid Assets of Islamic Banks (LAIB), Net Income of Islamic banks (NIIB), In addition to the Total Bank Deposits (TDIB) \& Total Bank Facilities (TFIB) which previously were tested in last papers, while the economic growth (dependent variable) will be represented by the real gross domestic product (RGDP).

\section{The Study Objective}

The objective of this paper is to study the Impact of Jordan's Conventional and Islamic Banking Development Factors on Economic Growth during the period (2000-2015). The Islamic banking development factors (Independent variables) consist of Total Assets of Islamic banks (TAIB), Liquid Assets of Islamic Banks (LAIB), Net Income of Islamic banks (NIIB), Total Bank Deposits (TDIB) and Total Bank Facilities (TFIB), while the Economic Growth (Dependent variable) include the real gross domestic product (RGDP).

\section{Literature Review}

Most of the studies assessing the impact of (FD) Financial Development on (EG) Economic Growth had concentrated at conventional banks rather than Islamic banks. In general this issue has not been extensively studied in the Literature field of Islamic banks. Some studies covered the issue as follows:

Hokayem and Hokayem (2015) studied the relationship between financial development \& economic growth in Lebanon during the period (1970-2012). The results revealed bidirectional causality between certain indicators that reflect the financial development and economic growth. The financial development indicators such as Bank Deposits relative to assets of central bank, Bank Assets to GDP, Credit to GDP \& Liquid liabilities to GDP have a positive correlation with Economic Growth, while financial repression such as (Inflation Rate \& Ratio of central bank assets to GDP were negatively correlated with economic growth.

Aloqool, Okab, and Bashayreh (2014) explored the relationship between (FIBD) Financial Islamic banking development \& (EG) Economic Growth in Jordan. Facilities (FINC) \& Deposits (DEPT) were used as a measure of FIBD While RGDP used as indicator of EG .The findings showed bi-directional long run granger causality between RGDP \& FINC reflecting a positive contribution for Jordanian Islamic banks. The relation appeared unidirectional between RGDP \& DEPT reflecting the excess liquidity problem for all Jordanian Islamic banks.

Farahani and Dastan (2013) showed the effect of Islamic banks' financing on economic growth of selected Islamic countries. The researchers applied the FMOLS model. Results appeared a significant relation in both short run \& long run for the selected countries.

Hassanudin et al. (2013) examined the relationship between FD \& EG in Bahrain dual financial system .Co-integration test \& VECM were applied .The results showed a strong long run relation with bi-directional causality in Islamic finance, while it was uni-directional causality for conventional finance.

Muhammad and Mohd (2012) examined the short-run and the long-run relationships between Islamic banking development and economic growth in the case of Indonesia by using quarterly data (2003:1-2010:2). They utilized the bound testing approach of cointegration and error correction models, developed within an autoregressive distributed lag (ARDL) framework. The results demonstrated a significant relationship in short-run and long-run periods between Islamic financial development and economic growth.

Abduh and Chowdhury (2012) examined the long run and dynamic relationship between Islamic banking development and economic growth in the case of Bangladesh. The quarterly time-series data of economic growth, total financing and total deposit of Islamic banking from Q1:2004 to Q2:2011 were used. It was found to have a positive and significant relationship with economic growth both in the long and short run. It reached that the development of Islamic banking was one of the policies, which should be considered by the government to improve their income.

Goaied and Sassi (2011) explored the relationship between the financial development and growth in some countries in the Middle East and North Africa (MENA) region. Empirical results showed an insignificant relationship between banking and growth which reinforce the idea that banks didn't spur economic growth. Besides, also it was found that credit to private sectors affected negatively with economic growth.

Christopoulos and Tsionas (2004) examined the relationship between financial development \& growth in ten developing countries. They found long term causality from financial development to growth, but absence of 
short term relationship between the two variables. In addition they found one single co integration vector between finance \& Economic Growth.

Rioja and Valen (2002) found that financial development affects economic growth in low-income countries through capital accumulation, while increasing productivity of high income countries serves as "transmission belt".

Beck And Levine (2001) showed that industries with greater need for external funding develop proportionately faster in countries with more developed financial systems.

Rajan and Zingales (1998) were the first to address the link between finance \& growth through the most possible micro data on industry or cross-country levels. They found a positive and significant coefficient of correlation at level $1 \%$ between dependency to external financing and financial development indicators which tend to show that the greater degree of financial development promotes growth in sectors most dependent on external financing.

King and Levine (1993) showed that the financial indicators (the size of financial sector relative to gross domestic product, the ratio of private credit to GDP) were highly correlated with capital accumulation and thus to economic growth .

On the basis of existing literature, this study examined \& compared the impact of Jordan's Conventional and Islamic Banking Development Factors on Economic Growth during the period (2000-2015).

\section{The Study Population and Sample}

In This study, researcher considered four Islamic banks and eight conventional banks in Jordan during the period (2000-2015). Islamic banks - included Jordan Islamic Bank, Islamic International Arab Bank, Jordan Dubai Islamic Bank \& AL Rajhi Bank. While Conventional Banks included Jordan Kuwait Bank, Arab Jordan Investment Bank, Jordan Commercial Bank, Invest Bank, Arab Banking Corporation -Jordan, Bank Al Etihad, Societe General Jordan and Capital Bank. The Researcher gathered all of above mentioned banks as a study sample. Table 1 show that Jordan Kuwait Bank (1977) was the oldest among Conventional banks, while Jordan Islamic bank (1978) was the oldest among Islamic banks. In Addition, Jordan Islamic Bank has the largest total assets around 3.8 billion Jordanian Dinar and the largest number of employees (2051), while Al Rajhi has the lowest size 442.3 million JD and lowest number of employees (147). Regarding conventional banks Jordan Kuwait Bank has the largest total assets 2885 billion, while invest bank has the lowest 845.4 million JD. Also Jordan Kuwait Bank has the largest number of employees 1002 while Societe General Jordan has the lowest employees (232). A comparison was conducted between 4 Islamic banks existed in Jordan in 37 years of establishment since 1978 and eight conventional banks. Although it's not a good number to show the importance of Islamic banking in Jordan as compared to conventional, Author can justify this issue as experts expect the number of Islamic banks to increase in future due to the political and economic conditions improve. Indeed, Studies expect Islamic banking assets to grow at a Compounded Average Growth Rate of 20\% over (2013-2020) across the countries to reach US $\$ 3.034$ trillion by 2020 (AL-Hersh, 2014).

Table 1. Bank sample characteristic

\begin{tabular}{|c|c|c|c|c|}
\hline Bank Name / Type & /Year Established & $\begin{array}{c}\text { Size Total Assets (Millions } \\
\text { JOD) }\end{array}$ & No. of Employees & Total working Banks \\
\hline Islamic Banks & & & & 4 \\
\hline Jordan Islamic Bank & 1978 & 3799 & 2051 & $*$ \\
\hline Islamic International Arab & 1997 & 1808.6 & 795 & $*$ \\
\hline Jordan Dubai Islamic Bank & 2009 & 780.1 & 357 & $*$ \\
\hline AL Rajhi Bank & 2011 & 442.3 & 147 & $*$ \\
\hline Total & ----- & 6830 & 3350 & 4 from 4 Banks \\
\hline Conventional Banks & & & & 21 \\
\hline Jordan Kuwait Bank & 1977 & 2884.7 & 1002 & $*$ \\
\hline Arab Jordan Investment Bank & 1978 & 1793.2 & 746 & $*$ \\
\hline Jordan Commercial Bank & 1978 & 1487.6 & 769 & $*$ \\
\hline Invest Bank & 1989 & 845.4 & 381 & $*$ \\
\hline Arab Banking Corporation & 1989 & 1029 & 489 & $*$ \\
\hline Bank Al Etihad & 1991 & 2389.1 & 848 & $*$ \\
\hline Societe General Jordan & 1993 & 1210.10 & 232 & $*$ \\
\hline Capital Bank & 1996 & 1986.20 & 557 & $*$ \\
\hline Total & ------- & 13625.30 & 5024 & 8 from 21 banks \\
\hline
\end{tabular}


Source: Association of Banks in Jordan ABJ ; Thomson Reuters.

\section{Method of Data Collecting}

Theoretical framework was collected from different sources such as book articles, relevant literature \& annual reports of Jordanian Conventional and Islamic Banks. The data that collected from (Reuters, 2016) and the annual reports of Jordanian Islamic Banks focused on the following variables:

Independent variables:

Total Assets of Islamic banks (TAIB).

Liquid Assets of Islamic Banks (LAIB).

Total Deposits of Islamic banks (TDIB).

Total Facilities of Islamic banks (TFIB).

Net Income of Islamic banks (NIIB).

Dependent variables:

The Real Gross Domestic Product (RGDP).

\section{Data Treatment}

The study used the multiple regression analysis to explore the effect of independent variables illustrated with Islamic banking development on the dependent variable (Economic Growth). A measure was used to evaluate the Dependent Variable Economic growth through the RGDP, while independent variables represented through Total Finance (FINC) and Total Deposits (Dept) Aloqool, Okab, and Bashayreh (2014). Researcher added new independent variables such as the Total Assets of Islamic banks (TAIB), Liquid Assets of Islamic Banks (LAIB) and the Net Income of Islamic banks (NIIB) as new contribution in this study. These new variable will make new value added in comparative process between conventional and Islamic banks.

The analysis of the data collected from Jordanian Banks was followed a number of statistical techniques such as Multiple Regressions, Correlation, Variance Inflation Factor (VIF), F-Test and T-test. Multicollinearity explores the correlation between independent variables through Variance Inflation Factor (VIF) .

\section{Study Model}
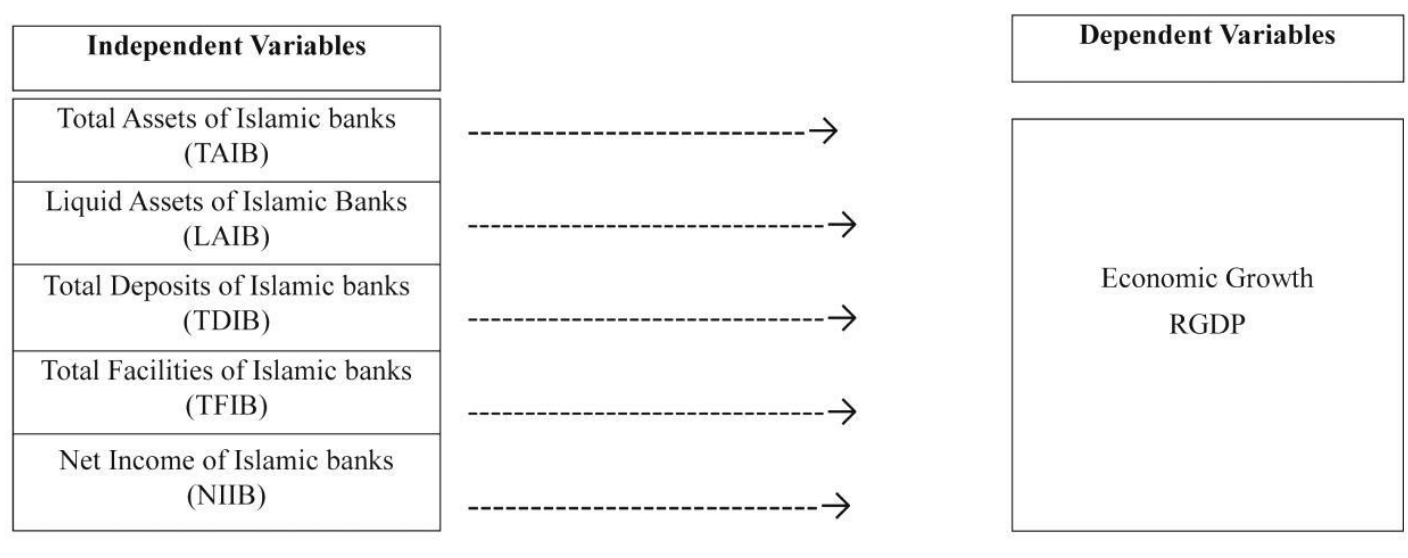

\section{Study Hypothesis}

The researcher formulated the null hypothesis regarding to the study problem as follows:

H01: There is no significant different between the impact of Conventional and Islamic Banking Factors on RGDP attributed to Total Assets (TA).

H02: There is no significant different between the impact of Conventional and Islamic Banking Factors on RGDP attributed to Liquid Assets (LA).

H03: There is no significant different between the impact of Conventional and Islamic Banking Factors on RGDP attributed to Total Deposits (BD).

H04: There is no significant different between the impact of Conventional and Islamic Banking Factors on 
RGDP attributed to Bank Facilities (BF).

H05: There is no significant different between the impact of Conventional and Islamic Banking Factors on RGDP attributed to Net Income (NI).

\section{Findings, Data Analysis \& Recommendations}

\subsection{Hypothesis Testing and Results}

Multicollinearity can be controlled by two ways: Tolerance value and value of variance Inflation Factor (VIF) (Hair et al., 1998). Multicollinearity appears if the tolerance is less than 0.10 or VIF value is more than 10. Table (2) shows that tolerance for all independent variables is more than 0.10 and variance inflation factor - VIF is less than 10 , so there is no Multicollinearity problem.

Table 2. Tolerance and variance inflation factor - VIF

\begin{tabular}{lcc}
\hline \multicolumn{1}{c}{ Variables } & Tolerance & VIF \\
\hline Total Assets of Islamic banks (TAIB) & 0.11 & 9.314 \\
Liquid Assets of Islamic Banks (LAIB) & 0.67 & 1.500 \\
Total Deposits of Islamic banks (TDIB) & 0.19 & 5.381 \\
Total Facilities of Islamic banks (TFIB) & 0.40 & 2.439 \\
Net Income of Islamic banks (NIIB) & 0.30 & 3.356 \\
\hline
\end{tabular}

According to decision rule: we will reject (H0) if the sig level is equal or less than 0.05 (Sekran, 2003). In addition, the researcher tested statistically the proposed hypothesis \& found the results as follows:

$$
E G=\alpha+(b 1 * T A I B)+(b 2 * L A I B)+(b 3 * T D I B)+(b 4 * T F I B)+(b 5 * N I I B)+\epsilon
$$

Where: EG: Economic Growth

TAIB: Total Assets of Islamic banks.

LAIB: Liquid Assets of Islamic Banks.

TDIB: Total Deposits of Islamic banks.

TFIB: Total Facilities of Islamic banks.

NIIB: Net Income of Islamic banks.

$\alpha$ : The Constant

b1, b2, b3, b4, b5: The parameter to be estimated.

$€$ : The Error.

Also the researcher tested the correlation between the variables of study. As shown in Table 3 the coefficients of correlations between the independent variables \& RGDP (Dependent variable) were highly positive for most variables; coefficients of Pearson correlation were between (0.642-0.996) for Islamic banks and (0.393-0.99) for conventional banks.

Table 3. Results of correlation of coefficients

\begin{tabular}{lcc}
\hline \multicolumn{1}{c}{ Variables } & Correlation with RGDP & Sig (2 Tailed) \\
\hline Total Assets of Islamic banks (TAIB) & 0.981 & 0.000 \\
Total Assets of Conventional banks (TACB) & 0.990 & 0.000 \\
Liquid Assets of Islamic Banks (LAIB) & 0.642 & 0.007 \\
Liquid Assets of Conventional Banks (LACB) & 0.393 & 0.132 \\
Total Deposits of Islamic banks (TDIB) & 0.980 & 0.000 \\
Total Deposits of Conventional banks (TDCB) & 0.975 & 0.000 \\
Total Facilities of Islamic banks (TFIB) & 0.996 & 0.000 \\
Total Facilities of Conventional banks (TFCB) & 0.988 & 0.000 \\
Net Income of Islamic banks (NIIB) & 0.905 & 0.000 \\
Net Income of Islamic banks (NICB) & 0.879 & 0.000 \\
\hline
\end{tabular}


T-Test was used to test the null hypothesis of the equality of means between the two samples (Conventional and Islamic) Banks in order for our comparison more reliable and meaningful. In addition, multiple regression was used to test the relationship between independent variables \& dependent variable (RGDP) in order to study the answers of the study (Abu Zaid, 2005); Table (4) reveals the results of hypotheses as follows:

Table 4. Comparison between conventional and Islamic banks

\begin{tabular}{|c|c|c|c|c|c|c|}
\hline Variables & $\begin{array}{c}* \\
\text { Mean Million } \\
\text { JOD }\end{array}$ & $\begin{array}{c}* \\
\text { Standard } \\
\text { Deviation }\end{array}$ & $\begin{array}{l}* * \\
\text { df }\end{array}$ & $\begin{array}{c}* * \\
\mathrm{~T} \text { value }\end{array}$ & $\begin{array}{c}* * * \\
\text { Sig For both } \\
\text { Sample T-test }\end{array}$ & $\begin{array}{c}* * * \text { Sig } \\
\text { For each sample } \\
\text { Regression }\end{array}$ \\
\hline Total Assets of Islamic banks (TAIB) & 1062.43 & 398.59 & 15 & 5.439 & 0.000 & 0.001 \\
\hline Total Assets of Conventional banks (TACB) & 853.22 & 457.902 & & & & 0.155 \\
\hline Liquid Assets of Islamic Banks (LAIB) & 372.82 & 111.15 & 15 & 8.600 & 0.035 & 0.033 \\
\hline Liquid Assets of Conventional Banks (LACB) & 174.51 & 47.63 & & & & 0.950 \\
\hline Total Deposits of Islamic banks (TDIB) & 916.15 & 325.39 & 15 & 7.688 & 0.000 & 0.000 \\
\hline Total Deposits of Conventional banks (TDCB) & 590.03 & 389.06 & & & & 0.705 \\
\hline Total Facilities of Islamic banks (TFIB) & 624.55 & 358.51 & 15 & 6.053 & 0.000 & 0.000 \\
\hline Total Facilities of Conventional banks (TFCB) & 398.206 & 220.279 & & & & 0.178 \\
\hline Net Income of Islamic banks (NIIB) & 10.53 & 6.23 & 15 & -1.511 & 0.151 & 0.070 \\
\hline Net Income of Islamic banks (NICB) & 11.96 & 6.78 & & & & 0.051 \\
\hline
\end{tabular}

Source: * Computation from data used in Descriptive Statistics.

** Computation from data used in T-Test.

*** Computation from data used in Regression Analysis.

\section{Hypothesis 1}

H01: There is no significant different between the impact of Conventional and Islamic Banking Factors on RGDP attributed to Total Assets (TA).

As shown in Table 4, the significant level is 0.000 which it is less than 0.05 , so we will reject the null hypothesis and as a result there is significant different between the impact of Conventional and Islamic Banking Factors on RGDP attributed to Total Assets (TA). The impact of Total assets of Islamic Banks on RGDP is significant (0.001) but it is not significant for conventional banks (0.155). Mean for Islamic Banks 1062.43 million JOD and 853.22 million JOD for conventional. Thus Total Assets of Islamic Banks (LAIB) can predict the economic growth in Jordan.

\section{Hypothesis 2}

H02: There is no significant different between the impact of Conventional and Islamic Banking Factors on RGDP attributed to Liquid Assets (LA).

The significant level equal 0.035 which it is less than the determined value (0.05), so the null hypothesis will be rejected. We can conclude that there is significant statistical impact of Liquid Assets of Islamic Banks (LAIB) on Economic Growth as the impact is significant for LAIB (0.033) but it is not significant for Conventional banks LACB (0.950). This result explained the liquidity problems that the Islamic Banks suffer from due to lack of financial and investment products in Islamic banking sector in Jordan.

\section{Hypothesis 3}

H03: There is no significant different between the impact of Conventional and Islamic Banking Factors on RGDP attributed to Total Deposits (TD).

We rejected H03 as the significant level (0.000) is less than the determined value (0.05). The mean is 916.15 million JOD for Islamic Banks while it is 590.03 million for Conventional. The impact of Total Deposits of Islamic Banks on RGDP is significant (0.000). It is not significant for conventional banks (0.905), so the Total Deposits of Islamic banks (TDIB) have impact on Economic Growth (RGDP).

Hypothesis 4

There is no significant different between the impact of Conventional and Islamic Banking Factors on RGDP attributed to Total Facilities (TF).

As shown on Table 4, Sig is (0.000) which it is less than 0.05 , so the null hypothesis H04 will be rejected. The 
Total Facilities of Islamic banks considered as an effective factor that impact on (EG) Economic Growth. The results showed that mean of total facilities for both conventional \& Islamic banks are 624.55 and 398.206 million respectively. The total Facilities of Islamic banks will be big indicator for Economic Growth because of positive correlation between the Total Facilities of Islamic banks \& Economic Growth.

Hypothesis 5

There is no significant different between the impact of Conventional and Islamic Banking Factors on RGDP attributed to Net Income (NI).

Based upon the results on Table 4, the null hypothesis can't be rejected as the significant level is more than 0.05 (0.151). The mean is congruent between the conventional and Islamic banks (11.96, 10.53 million JOD respectively), so there is no significant different between the impact of Conventional and Islamic Banking Factors on RGDP attributed to Net Income (NI).

\section{Finding Discussion}

After testing the hypothesis and analyzing the data, it was found that:

The total Assets of Islamic banks (TAIB) have significant statistical impact on Economic Growth. This is supported by Hokayem and Hokayem (2015) who found that the ratio of commercial banks assets to GDP as indicator of financial development has a positive correlation with (EG) Economic Growth.

Liquid Assets of Islamic Banks (LAIB) have a significant statistical impact on Economic Growth. The results suggested that the Islamic Banks should increase the liquid assets because of the positive correlation between the liquid assets \& Economic growth. Liquid assets measure the ability of firm's commitments toward to policyholders \& other creditors through liquidating the financial assets quickly, easily and without losses. That reflects the Jordanian Islamic banks to cover any immediate commitments \& strengthen the operational performance and leads to Economic Growth. We can conclude that Liquidity surplus one of the most important issue in Islamic banks due to lack of financial and investment products in Islamic banks in Jordan.

Total Deposits of Islamic banks (TDIB) have a significant statistical impact on Economic Growth (RGDP). This finding is supported by Hokayem and Hokayem (2015) who discovered a positive correlation between the bank deposits and economic growth. The results also consistent with ALOqool, Okab \& Basayreh (2014) who found a long -run relationship between the total Deposits of Islamic Banks and EG variable (RGDP).

The Total Facilities of Islamic banks (TFIB) considered as an effective factor that impact on (EG) Economic Growth. This finding is consistent with those obtained by ALOqool, Okab and Basayreh (2014); Hassanudin et al. (2013) in Bahrain dual financial system; Abduh and Chowdhury (2012) in the case of Bangladesh; Christopoulos and Tsionas (2004) in the case of ten developing countries) who stated the existence of a long run relationship between the total financing in the tested countries and EG variable.

Regarding The Net Income (NIIB) variable; No significant different found between the impact of Conventional and Islamic Banking Factors on RGDP attributed to Net Income (NI).

\section{Recommendations}

Based on the research findings, the researcher presented many recommendations as follows:

Economist, researcher \& investment decision makers can rely on the indicators of Islamic banking factors such as Total Assets, Liquid Assets, Total Deposits and Total Facilities because Islamic banks have impact on Economic growth more than conventional banks as it showed in the result of the study.

Economic Growth is highly affected by the Liquid assets which measured the ability of the banks to face commitments toward policyholders \& other creditors through liquidating the financial assets quickly, easily and without losses. Thus highlight the importance of product development department in Islamic banks to solve surplus liquidity through new solutions.

Great attention should be taken to Total Deposits of Islamic banks (TDIB). Executive management in Jordanian Islamic banks should introduce new innovative financial instruments and tools to push the economic growth forward in Jordan. This will increase the investment opportunity and lead to higher contribution to EG in Jordan.

\section{References}

Abduh, M., \& Chowdhury, N. (2012). Does Islamic banking matter for Economic Growth in Bangladesh? Journal of Islamic Economics Banking \& Finance, 8(3), 104-113.

ABJ Annual Report. (2014). Issue No. 36, Association of Banks in Jordan - ABJ. 
Abu Zaid, M. (2005). Methods of Statistical Analysis using SPSS Software - Version 10-12. Amman, pp. 259.

AL-Hersh, N. (2014). The advancement of Islamic banking and finance in global markets. International Journal of Interdisciplinary and Multidisciplinary Studies (IJIMS), 1(8), 11-18.

AL-Hersh, N. (2015). Jordan continues to be main player in the Islamic finance Industry. IFN: Islamic Finance News- 2016 Guide, p. 85.

ALOqool, M., Okab, R., \& Basayreh, M. (2014). Financial Islamic Banking Development \& Economic Growth: A case study of Jordan. International Journal of Economics \& Finance, 6(3), 72-79. http://dx.doi.org/10.5539/ijef.v6n3p72

AL-Rajhi Bank. (2012). Annual Financial Report. Retrieved from http://www.alrajhibank.com.jo

Beck, T., \& Levine, R. (2001). Stock markets, Banks and Growth: Correlation or Causality. World Bank policy research working paper N 2670, Carlson school of management working paper.

Christopoulos, D., \& Tsionas, E. (2004). Financial Development \& Economic Growth: Evidence from panel unit root \& cointegration tests. Journal of Development Economics, 73, 55-74. http://dx.doi.org/10.1016/j.jdeveco.2003.03.002

Farahani, Y., \& Dastan, M. (2013). Analysis of Islamic banks financing and economic growth: A panel cointegration approach. International Journal of Islamic and Middle Eastern Finance and Management, 6(2), 156-172. http://dx.doi.org/10.1108/17538391311329842

Goaied, M., \& Sassi, S. (2011). Financial Development, Islamic banking and Economic Growth: Evidence from Mena Region. International Journal of Business \& Management Science, 4(2), 105-128.

Hair J., Anderson, R., Tatham, R., \& Black, W. (1998). Multivariate data analysis. Upper Saddle River, NJ: Prentice-Hall.

Hassanudin et al. (2013). Do Islamic banks contribute to the economic growth than conventional banks? The empirical investigations of Bahrain dual banking. International Journal of Science Commerce \& Humanities, 1(3), 86-116.

Hokayem, E., \& Hokayem, N. (2015). Financial development \& Economic growth in Lebanon. Arab banking Review.

Islamic International Arab Bank. (1998). Annual Financial Report. Retrieved from http://www.iiabank.com.jo

Jordan Dubai Islamic Bank. (2010). Annual Financial Report. Retrieved from http://www.jdib.jo

Jordan Islamic Bank. (1980). Annual Financial Report. Retrieved from http://www.jordanislamicbank.com

King, R., \& Levine, R. (1993). Finance \& Growth: Schumpeter might be right? Quarterly Journal of Economics, 108, 717-737. http://dx.doi.org/10.2307/2118406

Muhamad, A., \& Mohd, A. (2012). Islamic banking \& economic growth: The Indonesian experience. International Journal of Islamic \& Middle Eastern Finance \& Management, 5(1), 35-47. http://dx.doi.org/10.1108/17538391211216811

Rajan, R., \& Zingales, L. (1998). Financial Dependence and Growth. American Economic Review, 88, 559-586.

Reuters, T., \& Zawya. (2016). Retrieved from http://www.zawya.com/

Rioja, F., \& Valen, N. (2002). Finance \& The source of Growth at various stages of economic development. University of Georgia State, Andrew Young School of policy studies, working paper 02-17.

Sekran, U. (2003). Research methods for business a skill building approach (4th ed.). Johan Wiley \& Sons, Inc.

The Banker Report. (2015). Special Report for Top Islamic Financial Institutions.

Thomson Reuters Report. (2015). State of the Global Islamic Economy Report.

\section{Copyrights}

Copyright for this article is retained by the author(s), with first publication rights granted to the journal.

This is an open-access article distributed under the terms and conditions of the Creative Commons Attribution license (http://creativecommons.org/licenses/by/4.0/). 